\title{
A New Method to Obtain an Initial Basic Feasible Solution of Transportation Problem with the Average Opportunity Cost Method
}

\author{
Swati V. Kamble, Bhausaheb G. Kore
}

\begin{abstract}
In this preset article, we have explained all new method to get Initial Basic Feasible solution (IBFS) of Transportation Problem (TP) with the Average Opportunity Cost Method (AOCM). It is very simple arithmetical and logical calculation. After finding the IBFS we use Modified Distribution Method (MODI) method to optimize the IBFS. Results obtained by using this method we found that IBFS of most of the transportation problem closer to optimal solution than using the other existing methods. We illustrate the same by suitable examples.
\end{abstract}

Keyword: AOCM, IBFS, MODI, Optimal Solution, TP.

\section{INTRODUCTION}

Transportation Problem is a specific part of linear programming problem which is applied in real life. It is helpful for the solving TP on distribution and transportation of resources between places. Main role of TPs is to minimize the total transportation cost of shipping units between places. Some well-known methods to find the minimum transportation cost are North West Corner Method (NWCM), Least Cost Method (LCM) \& Vogel's Approximation Method (VAM) are considered to provide the better Initial Basic Feasible Solution (IBFS) and for optimality check we can use MODI method.

In last few years many methods are proposed to find IBFS of TP, Kore B. G. (2008) proposed Row Penalty Method and Column Penalty Method for finding IBFS of TP. M.W Ullah, M. Alhaz Uddin and Rijwaana Kauser (2016) proposed a new method "A Modified Vogel's Approximation method for obtaining a good primal solution of transportation problem". Duraphe S and Raigar S (2017) obtain" A new approach to solve transportation problems with the max-min total opportunity cost method". S.M.Abool Kalaam Aazad,Md. Belleil Hosain,Md .M Rahman (2017)" An Algorithmic Approach to solve Transportation Problems with the Avg Total Opportunity cost method". S.M.Abool Kalaam Aazad, Md. Bellel Hosain (2017) developed a new method for solving transportation problems considering average penalty.A.R.Khaan, Adreian vilcu, Md. sharrif Uddin and florin Ungurenu (2015) proposed a competent Algorithm to find the IBFS of cost minimization transportation problem.

Revised Manuscript Received on December 30, 2019.

* Correspondence Author

Swati V. Kamble*, Research Scholar, Department of Statistics, Shivaji University, Kolhapur, India,

Bhausaheb G. Kore, Principal, Adarsh College, Vita - 415 311, Dist.: Sangli (M. S.), Affiliated to Shivaji University, Kolhapur, INDIA.

(C) The Authors. Published by Blue Eyes Intelligence Engineering and Sciences Publication (BEIESP). This is an open access article under the CC BY-NC-ND license (http://creativecommons.org/licenses/by-nc-nd/4.0/)
In this paper, we have developed a new method AOCM to obtain IBFS. Using this method we find the IBFS of most of the TP closer to optimal solution than using the other existing method. Results of some examples of TP are same to optimal solution. Which is a very simple and easy to understand.We illustrated the numerical examples for the new method and comparing these result to NWCM, LCM and VAM.

\section{MATHEMATICAL FORMULATION}

The transportation problem is shown as a linear transportation model as below,

Minimize,

$$
\mathrm{Z}=\sum_{\mathrm{i}=1}^{\mathrm{n}} \sum_{\mathrm{j}=1}^{\mathrm{m}} \mathrm{C}_{\mathrm{ij}} \mathrm{X}_{\mathrm{ij}}
$$

where,

$$
\begin{aligned}
& \sum_{j=1}^{m} X_{i j}=a_{i}, \quad i \quad=1,2, \ldots \ldots \ldots n \text { (Supply) } \\
& \sum_{i=1}^{n} X_{i j}=b j, \\
& j=1,2, \ldots \ldots \ldots \ldots, m \text { (demand) }
\end{aligned}
$$$$
\text { And } \quad X_{i j} \geq 0 \text {, for all } i \text { and } j \text {. }
$$

Where,

$$
\mathrm{X}_{\mathrm{ij}}=\text { The quantity to be shipped from } \mathrm{i}^{\text {th }} \text { origin to } \mathrm{j}^{\text {th }}
$$
destination.

$\mathrm{C}_{\mathrm{ij}}=$ per piece(unit) cost in shipping from $\mathrm{i}^{\text {th }}$ origin to $\mathrm{j}^{\text {th }}$ destination.

$\mathrm{a}_{\mathrm{i}}=$ The amount available at $\mathrm{i}^{\mathrm{th}}$ origin.

$\mathrm{b}_{\mathrm{j}}=$ The demand available at $\mathrm{j}^{\text {th }}$ destination.

\section{ALGOTITHM OF AOCM}

STEP 1. Subtract smallest cost from every element of every row of transportation table and put it on right top of that element.

STEP 2. Subtract the smallest cost from every element of every column of transportation table and put it on right bottom of that element.

STEP 3. Create a new matrix whose elements are average value of right top and right bottom of elements of step 1 and step 2 .

STEP 4. Find Row \& Column penalties by taking difference between smallest \& next smallest value in row \& column. 
A New Method to Obtain an Initial Basic Feasible Solution of Transportation Problem with the Average Opportunity Cost Method

STEP 5. Identify the largest penalty and allocate the maximum possible quantity to that cell having minimum value of element in corresponding row or column. If there is a tie between largest penalties, then tie can be broken by taking difference between smallest and next to smallest element, if tie still not broken then repeat the procedure with next to next smallest and so on, if tie still not broken then select arbitrarily.
STEP 6. Repeat step 5 to step 6 until the rim requirement is satisfied.

STEP 7. Put these allocated values in original TT in corresponding cell.

STEP 8. Calculate the transportation cost of TT. This calculation is the sum of product of unit transportation cost and allocated quantity.

\section{NUMERICAL EXAMPLES}

4.1 Solve Following TP:

\begin{tabular}{|c|c|c|c|c|c|}
\hline & $\mathrm{D}_{1}$ & $\mathrm{D}_{2}$ & $\mathrm{D}_{3}$ & $\mathrm{D}_{4}$ & Supply \\
\hline $\mathrm{W}_{1}$ & 9 & 8 & 5 & 7 & 12 \\
\hline $\mathrm{W}_{2}$ & 4 & 6 & 8 & 7 & 14 \\
\hline $\mathrm{W}_{3}$ & 5 & 8 & 9 & 5 & 42 \\
\hline Demand & 8 & 18 & 13 & 3 & \\
\hline
\end{tabular}

Solution:

\begin{tabular}{|c|c|c|c|c|c|}
\hline & $\mathrm{D}_{1}$ & $\mathrm{D}_{2}$ & $\mathrm{D}_{3}$ & $\mathrm{D}_{4}$ & Supply \\
\hline $\mathrm{W}_{1}$ & $9_{5}^{4}$ & $8_{2}^{3}$ & $5_{0}^{0}$ & $7_{2}^{2}$ & 12 \\
\hline $\mathrm{W}_{2}$ & $4_{0}^{0}$ & $6_{0}^{2}$ & $8_{3}^{4}$ & $7_{2}^{3}$ & 14 \\
\hline $\mathrm{W}_{3}$ & $5_{1}^{0}$ & $8_{2}^{3}$ & $9_{4}^{4}$ & $5_{0}^{0}$ & 16 \\
\hline Demand & 8 & 18 & 13 & 3 & 42 \\
\hline
\end{tabular}

Prepare reduced Matrix and calculate penalties

\begin{tabular}{|c|c|c|c|c|c|c|c|c|c|c|}
\hline & $\mathrm{D}_{1}$ & $\mathrm{D}_{2}$ & $\mathrm{D}_{3}$ & $\mathrm{D}_{4}$ & $\mathrm{a}_{\mathrm{i}}$ & $\mathrm{P}_{1}$ & $\mathrm{P}_{2}$ & $\mathrm{P}_{3}$ & $\mathrm{P}_{4}$ & $\mathrm{P}_{5}$ \\
\hline $\mathrm{W}_{1}$ & 4.5 & 2.5 & $12)_{0}$ & 2 & 12,0 & 2 & - & - & - & - \\
\hline $\mathrm{W}_{2}$ & 0 & 1 & 3.5 & 2.5 & 14,0 & 1 & 1 & 1 & 2.5 & \\
\hline $\mathrm{W}_{3}$ & 0.5 & 2.5 & 4 & 0 & $16,13,5,4,0$ & 0.5 & 0.5 & 2 & 1.5 & 1.5 \\
\hline $\mathrm{b}_{\mathrm{j}}$ & 8,0 & $18,4,0$ & $13,1,0$ & 3,0 & 42 & & & & & \\
\hline $\mathrm{P}_{1}$ & 0.5 & 1.5 & 3.5 & 2 & & & & & & \\
\hline $\mathrm{P}_{2}$ & 0.5 & 1.5 & 0.5 & 2.5 & & & & & & \\
\hline $\mathrm{P}_{3}$ & 0.5 & 1.5 & 0.5 & - & & & & & & \\
\hline $\mathrm{P}_{4}$ & - & 1.5 & 0.5 & - & & & & & & \\
\hline $\mathrm{P}_{5}$ & - & 2.5 & 4 & - & & & & & & \\
\hline
\end{tabular}

Now put allocation values in original matrix

\begin{tabular}{|c|c|c|c|c|c|}
\hline & $\mathrm{D}_{1}$ & $\mathrm{D}_{2}$ & $\mathrm{D}_{3}$ & $\mathrm{D}_{4}$ & $\mathrm{a}_{\mathrm{i}}$ \\
\hline $\mathrm{W}_{1}$ & 9 & 8 & 5 & 7 & 12,0 \\
\hline $\mathrm{W}_{2}$ & 4 & 6 & 8 & 7 & 14,0 \\
\hline
\end{tabular}




\begin{tabular}{|c|c|c|c|c|c|c|}
\hline $\mathrm{W}_{3}$ & 8 & 4 & 1 & 3 & $16,13,5,4,0$ \\
\hline $\mathrm{b}_{\mathrm{j}}$ & 8,0 & & 8 & 9 & 5 & $\mathbf{4 2}$ \\
\hline
\end{tabular}

The transportation cost is $\mathrm{Z}=12 * 5+14 * 6+8 * 5+4 * 8+1 * 9+3 * 5=240$

\subsection{Solve Following TP:}

\begin{tabular}{|c|c|c|c|c|}
\hline & W $_{1}$ & $\mathrm{~W}_{2}$ & $\mathrm{~W}_{3}$ & Supply \\
\hline $\mathrm{F}_{1}$ & 16 & 20 & 12 & 160 \\
\hline $\mathrm{F}_{2}$ & 14 & 8 & 18 & 90 \\
\hline $\mathrm{F}_{3}$ & 26 & 24 & 16 & 450 \\
\hline Demand & 180 & 120 & 150 & 200 \\
\hline
\end{tabular}

Solution:

\begin{tabular}{|c|c|c|c|c|}
\hline & $\mathrm{W}_{1}$ & $\mathrm{~W}_{2}$ & $\mathrm{~W}_{3}$ & Supply \\
\hline $\mathrm{F}_{1}$ & $16_{2}^{4}$ & $20_{12}^{8}$ & $12_{0}^{0}$ & 160 \\
\hline $\mathrm{F}_{2}$ & $14_{0}^{6}$ & $8_{0}^{0}$ & $18_{6}^{10}$ & 90 \\
\hline $\mathrm{F}_{3}$ & $26_{12}^{10}$ & $24_{16}^{8}$ & $16_{4}^{0}$ & 450 \\
\hline Demand & 180 & 120 & 150 & 400 \\
\hline
\end{tabular}

Prepare reduced Matrix \& calculate penalties

\begin{tabular}{|c|c|c|c|c|c|c|c|c|}
\hline 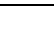 & $\mathrm{W}_{1}$ & $\mathrm{~W}_{2}$ & $\mathrm{~W}_{3}$ & $a_{i}$ & $\mathrm{P}_{1}$ & $\mathrm{P}_{2}$ & $\mathrm{P}_{3}$ & $\mathrm{P}_{4}$ \\
\hline $\mathrm{F}_{1}$ & 3 & 10 & 0 & $200,140,0$ & 3 & 3 & 3 & 3 \\
\hline $\mathrm{F}_{2}$ & 3 & 120 & 8 & $160,40,0$ & 3 & 5 & 5 & 3 \\
\hline $\mathrm{F}_{3}$ & 11 & 12 & 90 & 90,0 & 9 & 9 & - & - \\
\hline$b_{j}$ & $180,40,0$ & 120,0 & $150,60,0$ & 450 & & & & \\
\hline $\mathrm{P}_{1}$ & 0 & 10 & 2 & & & & & \\
\hline $\mathrm{P}_{2}$ & 0 & - & 2 & & & & & \\
\hline $\mathrm{P}_{3}$ & 0 & - & 8 & & & & & \\
\hline $\mathrm{P}_{4}$ & 0 & - & - & & & & & \\
\hline
\end{tabular}

Now put allocation values in original Matrix.

\begin{tabular}{|c|c|c|c|c|}
\hline & $\mathrm{W}_{1}$ & $\mathrm{~W}_{2}$ & $\mathrm{~W}_{3}$ & $\mathrm{ai}_{\mathrm{i}}$ \\
\hline $\mathrm{F}_{1}$ & 16 & 20 & 12 & $200,140,0$ \\
\hline $\mathrm{F}_{2}$ & 14 & 8 & 18 & $160,40,0$ \\
\hline $\mathrm{F}_{3}$ & 26 & 24 & 16 & 90,0 \\
\hline$b_{j}$ & $180,40,0$ & 120,0 & $150,60,0$ & 450 \\
\hline
\end{tabular}

The transportation cost is $\mathrm{Z}=140 * 16+60 * 12+40 * 14+120 * 8+90 * 16$

$=5920$ 
A New Method to Obtain an Initial Basic Feasible Solution of Transportation Problem with the Average Opportunity Cost Method

\section{COMPARISON BETWEEN RESULTS OF EXISTING METHODS AND PROPOSED METHOD}

\begin{tabular}{|c|c|c|}
\hline Method & Example 1 & Example 2 \\
\hline $\begin{array}{c}\text { Proposed Method } \\
\text { (AOCM) }\end{array}$ & 24020 \\
\hline NWCM & 320 & 6600 \\
\hline LCM & 248 & 6460 \\
\hline VAM & 248 & 5920 \\
\hline Optimal Solution & 240 & 5920 \\
\hline
\end{tabular}

\section{CONCLUSION}

From comparison table we can see that this new developed (AOCM) method is more effective than other existing and established methods wiz NWCM,LCM and VAM.The AOCM method which is totally new concept \& result oriented for both the bigger \& smaller size TP. The solution derived by this method is very close to optimal solution or same as optimal solution.

\section{ACKNOWLEDGMENTS}

I express my deepest sense of gratitude to Principal Dr. B. G. Kore, Research Guide, Associate Professor of Statistics, Adarsh College, Vita - 415311,Dist. Sangli(M.S.), for his invaluable guidance and continuous encouragement.

\section{REFERENCES}

1. Azad S.M.Abool Kalaam, Hosain Md. Bellel, Md. M Raheman (2017),"An Algorithmic Approach to solve Transportation Problems with the Average Total Opportunity cost method",International Journal of Scientific \& Research Publications, Vol.7,Issue 2.

2. Azad S. M. Abul Kalam, Hossain Md. Bellel (2017), "A New Method for Solving Transportation Problems Considering Average Penalty", IOSR Journal of Mathematics (IOSR-JM),Vol.13,Issue 1, PP 40-43.

3. Duraphe S. and Raigar S. (2017), "A New Approach to Solve Transportation Problems With the Max-Min Total Opportunity Cost Method", International Journal of Mathematics Trends \& Technology (IJMTT), Vol.51,No.4.

4. Hakeem M.A.(2012),"An Alternative Method to Find Initial Basic Feasible Solution of a Transportation Problem", Annals of Pure And Applied Mathematics, Vol.1, No.2,PP.203-209.

5. Khaan A.R.,Vilcu A., Uddin Md. S. \& Ungurenu F (2015),"A Competent Algorithm to Find The Initial Basic Feasible Solution of Cost Minimization Transportation Problem",Buletinul Institutului Politehnic Din Iasi,Tomul LXI (LXV),Fasc.2

6. Khaan A.R.,Vilcu A.,Sulatana N.\& Ahmed S.S. (2015),'Determination of Initial Basic Feasible Solution of A Transportation Problem: A TOCM-SUM Approach",Buletinul Institutului Politehnic Din Iasi,Tomul LXI (LXV),Fasc.1

7. Kore B. G. (2008), "A New Approach To Solve Unbalanced Transportation Problem", J. Indian Acad. Math. , vol.30, No.1, pp. 43-54 (2008).

8. Patel R.G, Bhathawala P.H (2016),'An Innovative Approach to Optimum Solution of a Transportation Problem",Vol.5, Issue 4.

9. Sharma J.K., "Operations Research Theory And Applications",Fifth Edition.

10. Ullah M.W , Uddeen M.A \& Kauser R (2016), “A Modified Vogel's Approximation Method for Obtaining A Good Primal Solution of Transportation Problems",Annals of Pure And Applied Mathematics, Vol.11, No.1,PP.63-71.

\section{AUTHOR'S PROFILE}



S. V. KAMBLE, obtained B. Sc in Statistics in Vivekanand College Kolhapur. M.Sc in Statistics in Shivaji University Kolhapur. Assistant Professor at Rajarshi Chhatrapati Shahu College, Kolhapur

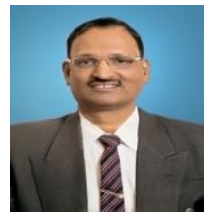

Dr. B. G. KORE, obtained B. Sc (1987) in Statistics in A.C.S College Miraj. M. Sc (1989) in Statistics in Shivaji University. D.C.P in Shivaji University. Ph. D (2004) under Dr. Babasaheb Ambedkar Marathawada University Aurangabad. Published 25 Research papers, Author of 18 Text books. 